\title{
Fostering eco-innovation in SMEs through bridging research, education and industry for building a business oriented model
}

\author{
Ileana HAMBURG \\ Institut Arbeit und Technik, Gelsenkirchen, Germany \\ Gabriel VLĂDUȚ \\ IPA-SA CIFATT, Craiova, Romania \\ Emma O'BRIEN \\ University of Limerick, Ireland
}

\begin{abstract}
Small and medium sized companies (SMEs) assure economic growth in Europe. The Environmental Technologies Action Plan (ETAP) concentrated and mobilized Member State and stakeholder efforts bringing eco-innovation from research to market, improving market conditions, opening up global markets. Rapid and reinforced actions are now required, building on the experience of ETAP helping SMEs to have benefits by introducing eco-innovative approaches into their operations. Particularly start-ups, can be the ideal incubators for eco-innovation, and can bring to market new, less environmentally damaging products, services and processes. Generally many SMEs are struggling to survive in an ongoing global recession and often they are becoming reluctant to release innovation, particularly eco-innovation (Assante et al., 2016). In this paper we present first the differences between eco-innovation based business models and those based on regular innovations. Secondly we give some approaches tested in national and European projects with participation of the authors in order to help SMEs to develop business models of eco-innovations. The first one is to build cooperation between researchers, educators and SME staff in order to explain SMEs the advantages of such models and to implement models designed by researchers. Secondly we used practice oriented forms of training for SMEs like Problem Based Learning (PBL) as an efficient form for SMEs and entrepreneurship education to learn to solve problems like the building of an eco-innovation business model. Thirdly we use in our projects eco-innovation biographies (EIBs) reflecting the evolutionary character of such innovations and the dynamics of related policy streams.
\end{abstract}

Keywords: Innovation, SME, E-learning, Business oriented model, Problem Based Learning (PBL), Cloud Computing.

\section{Introduction}

SMEs are drivers for innovation, job creation and growth. The challenges and opportunities of eco-innovation and taking into consideration that environmental pressures risk the longterm sustainability of SMEs, they should change their business models in this context.

In the last 25 years, the global economy has doubled - doubling use of resources. The economy is now five times bigger than 50 years ago, while the planet has fewer resources. For the fast-growing global population to achieve OECD levels of income by 2050, the economy would need to be 40 times bigger than now. Environmental pressures risk the long-term sustainability of the recovery. This is impossible; there must be fundamental change.

The Competitiveness and Innovation Framework Program (CIP) defines ecoinnovation as followed: "eco-innovation is any form of innovation aiming at significant and 
demonstrable progress towards the goal of sustainable development, through reducing impacts on the environment or achieving a more efficient and responsible use of natural resources, including energy".

In this program activities within eco-innovation process are classified as following:

- Activities of traditional eco-industries, which products and services related to pollution prevention and management, or natural resources management, can be PICBE | 1051 considered eco-innovation.

- Special activities where eco-innovation can reduce pollution and/or optimize resources use with a clear benefit for the environment and substantial improvements are eco-innovations.

In connection with differences between eco-innovations and regular innovations, some authors like Kempton (1991), Jaffe et al (1994), Kenzig and Wustenhagen (2008) present four characteristics of eco-innovations which influence investment decisions like the following:

- Eco-innovations often require high investments and a low operational cost that means a different ROI.

- Eco-innovations, could be characterized that the party taking the investment is not the party which receives the correlated benefits.

- Customers interested in eco-innovations are not enough experienced in decisions oriented to eco-innovations, they having often old surviving problems.

The Environmental Technologies Action Plan (ETAP) concentrated and mobilized Member State and stakeholder efforts bringing eco-innovation from research to market, improving market conditions, opening up global markets. In this context actions are required, built on the experience of ETAP.

The ETAP plan was adopted by the Commission in 2004 to cover a wide range of activities promoting eco innovation and use of environmental technologies. Its objective is to improve European competitiveness in this area, and enable the EU to become the recognized world leader.

\section{Eco-innovation business models}

Timmers (1998) gives a general understanding of what a business model is "architecture for the product, service and information flows. It gives a description of the various business actors and their roles, the potential benefits for the various actors and the sources of revenues". Generally every business organization has more business models. Schmidt et al. (2001) underlay that business models are not enough researched.

Two groups of business models have been defined:

- Business models characterized by the aim of value creation. Rappa (2001) and Turban (2002) define a business model as the method of doing business by which a company can generate value to sustain itself. Linder and Cantrell (2000) describe the business model as the organizations core logic to create value.

- Business models characterized by a more organizational point of view. Weil and Vitale (2001), define a business model as a description of roles and relationships among firm's consumers, customers, allies and suppliers that identifies the major flows of product, information, money and the major benefits to participants. 
Amit and Zott (2001) affirm that "a business model depicts the content, structure, and governance of transactions designed as to create value through the explosion of business opportunities. A business model includes the design of: transaction content (goods/services; resources/capabilities), transaction structure (parties involved; linkages; sequencing; exchange mechanisms), transaction governance (flow control). A business model describes the steps that are performed in order to complete transactions."

PICBE | 1052

Osterwalder and Pigneur (2009) define the business model as a conceptual tool that contains a set of elements and their relationships and allows expressing the business logic of a specific company. Support and governance structures, network, skills and funding sources are only emerging.

One problem is that the lack of public funding and access to private finance is difficult, as innovative SMEs are often young companies and eco-innovation is seen as more risky than other fields of innovation. Public policies must de-risk eco-innovation and provide the necessary incentives to spur and leverage private funding for green growth. A coordinated response is essential at local, national and global levels to overcome these difficulties.

We focus in our projects on bringing eco-innovation from research to market with support and new methodologies of personal formation that have, in our opinion an essential role on implementation of expectations, with efficiency, to promote competitiveness and internationalization, identification of market necessities. Rapid, concrete and efficient actions are required. The SMEs must be made aware and to understand advantages and benefits.

New regulation must promote competitiveness, eco-innovation, and performance indicators, must be regularly reviewed and up-dated, and be flexible to meet technical and expected process and impact. Some instruments must complement regulation - technology standards, procedures, methodologies, benchmarks, personal formation, product performance requirements and market-based instruments.

The extension of the eco-design should be based on the "think small first" principle in order for the SMEs to benefit from new product, services and process requirements and provide information, tools and sufficient time for adjustment.

The SMEs should be encouraged, stimulated and trained to introduce eco-innovative approaches in their business models and present advantages. Citizens must be made aware of the need for green products and services, through training, personal formation and labeling.

\section{SMEs and Eco-Innovation}

Small and medium sized companies (SMEs) assure economic growth in Europe. More than 99\% of European Union companies are SMEs, covering all sectors, including crafts, manufacturers and retailers. SMEs are responsible for two-thirds of private sector employment, and about $60 \%$ of EU GDP.

SMEs could have benefits by introducing eco-innovative approaches into their operations. Particularly start-ups, can be the ideal incubators for eco-innovation, and can bring to market new, less environmentally damaging products, services and processes.

Eco-innovation is important for SMEs by providing a market opportunity for entrepreneurs. 
Smaller companies identify a specific market demand and develop a new approach but unlike large companies, SMEs do not have existing markets to protect.

Research programs must sustain eco-innovation efforts and should motivate SME participation. SMEs should be supported to actively investigate emerging areas for ecoinnovation, including re-design of existing material chains, cross-sector research, and userled innovation, as well as improving dissemination and facilitating commercialization of PICBE | 1053 results.

Support measures must be developed for pre-and post-research activities, according TRL stipulations, including use of structural funds in synergy with R\&D\&I programs. SMEfriendly value chains and the eco-innovation must be created with the awareness of SMEs to form eco-innovative solutions and best practices.

Schemes should demonstrate effective verification and accreditation of ecoinnovation with technology manufacturers, solutions developers, investors and end users.

Some small companies grow into huge companies that are more innovative how to utilize the way business is done having also innovation departments.

Entrepreneurs also respond to market demand, and the demand for eco-innovative or sustainable products, services and processes is growing, meaning great opportunities for start-ups and small companies that offer genuine green innovations.

Generally many SMEs are struggling to survive in an ongoing global recession and often they are becoming reluctant to release innovation, particularly eco-innovation In the following we present some approaches to help SMEs to build eco-innovation business models (Hamburg presentation at UIN, Amsterdam, 2016).

The absence of collaboration between knowledge producers (academia) and knowledge users (industry) is real and frustrating and has a negative effect on the innovation and competitiveness of SMEs and ultimately affects the sustainable growth of corresponding countries. The gap between researchers and SME staff is sometimes deliberate, sometimes accidental caused by a misunderstanding of the requirements and objectives of the other.

Some of the reasons of the brain drain of researchers and entrepreneurs are; lack of interest from researchers for making their idea usable for practitioners, for transforming a research result in a practical product and commercialise it, different priorities (for the researcher a publication of an academicals paper is important, an entrepreneur's focus is to have success with the business), poor capability of SMEs to recognise the crucial importance of innovation for the sustainability of their businesses.

SMEs can often not articulate their research needs which could support their business; researchers probe new technologies, the boundaries, the problem in connection with them, practitioners have no time to deal with testing.

Policies focused almost exclusively on the support of transferring of research results to industry (into new products/services or improvements in existing ones) are missing. In following projects we build cooperation between researchers, educational experts and SMEs.

The second approaches we present is about innovative digital solutions for ecoinnovation learning in SMEs like Problem Based learning (PBL) (Hamburg, 2014).

It encourages innovation, both individual and cooperative work and thinking, a greater understanding of a topic due to active learning, engaging in the material. 
PBL increases motivation to learn thus developing a learning culture, developing skills in critical thinking, leadership, communication, problem solving. The Archimedes project (www.archimedes2014.eu) is an Erasmus project with partners from research, education and industry aimed at investigating the use of PBL in SMEs.

Survey Monkey questionnaires, Focus Group Discussions, Case Studies have been used in this context. PBL is supported in Archimedes by an ICT platform (www.archimedes- PICBE | 1054 tiki.eu), which contains training units for facilitator/trainer and also for the learners of the group.

Eco-innovation examples of problems to be solved have been included. The authors of this paper work in HE and VET and try to adopt eco-innovation in entrepreneurial education, particularly in higher education institutions and in SMEs (Hamburg, 2015).

The Erasmus+ project ENTER answers to problems concerning changing labor market and insufficient preparation to new situations by young people as well as lack of entrepreneurial education in formal systems The objective of this project with partners from Poland, Germany and UK is to teach entrepreneurial skills and opening people's mind also for eco-innovation and related activities by showing them advantages in both professional and everyday life. Laboratory sessions and conference have been organized for students and young entrepreneurs including eco-innovation issues.

The European EFEB Network's (http://efebnetwork.eu) main objective is to train, to mentor and to develop entrepreneurial skills of woman involving them in VET partnerships. The project has partners from 5 European countries and answers to the needs of entrepreneurial education, related also to developing eco-innovation modules and including them into the entrepreneurial education.

\section{Action to encourage partnership for public funding and private-sector investment.}

For models of development of SMEs, it is necessary to consider training models, training, used practical oriented forms of training, the entire value chain development provided by TRL, to have benefits by introducing eco-innovative approaches into their operations by new, less environmentally damaging products, services and processes. Education as the business opportunity presented by eco-innovation is necessary for private sector investors to change attitudes and to invest in this rapidly developing sector.

Meanwhile development models should work in innovative eco-systems, and functional complex that creates competitiveness and added value.

The models should provide support for SME's development through eco-innovation techniques, training, education, financing instruments, technology transfer strategies, effective collaboration and knowledge based on trust between producers (academy) and knowledge users (industry).

Essential elements of the European Commission agenda include support for an improved business and investment climate, especially for micro, small and medium-sized enterprises (MSMEs), and the strengthening of business intermediary and support organizations.

Public authorities should reduce the risk of eco-innovative investment.

- Cohesion policy must become an important element of bridging divergence in the development of eco-innovation and absorption.

- Establishing and strengthening the entrepreneurial community, integration and promotion of the entrepreneurial ecosystem. 
- Improving linkages within the entrepreneurship and innovation ecosystem.

- Tax incentives, economic instruments and financial instruments to stimulate private investment in this sector.

- Facilitate access to finance, allow mandatory pension funds and other institutional investors to invest in early stage companies or VC funds, supporting Business Angels. A dynamic and stimulative VC market, supporting by business angels, is an PICBE | 1055 essential condition for the success of eco-innovation.

- Speed up the development of a business angel culture by supporting the creation of business angel networks.

All jobs will increasingly involve an element of green. Green training is required in the first stage, including the integration of eco-innovation in technical education. Current training needs to be mapped to identify gaps and solving them through appropriate programs on both technical skills and management necessary eco-innovation.

This requires optimizing funding for national or regional initiatives to promote green business and technical skills. Organizations working with SMEs - trade associations, clusters, technological incubators and equipment suppliers - must be mobilized to help them continue to develop and implement innovative eco-solutions for their businesses.

Such networks should be encouraged to work together across industries and continents solutions parts, to improve dissemination of opportunities and challenges in eco-innovation and supply link and demand, especially for investors who match entrepreneurs and strengthening the link with applied research, in order to overcome the lack of R \& D in SMEs.

Mentoring schemes, corporate venturing, networking and clustering environmental enterprises should be explored to provide entrepreneurs with management skills needed green infrastructure to be successful. Partnerships with major enterprises are required to harness the transformative power of greening supply chains and to put into fabrication green products and services. The strategy should define the main challenges facing states and vision of transformation towards a green economy and sustainable. SMEs and green policies are an integral part of this solution. Now they must move towards implementation. A green deal for SMEs' should accelerate the development of eco-innovation.

\section{Eco-innovation biographies}

Eco-innovation biographies (EIBs) of successful and less successful initiatives are important in order to deepen understanding of development paths, knowledge trajectories and stakeholder interactions in eco-innovation processes.

Innovation biographies (IBs) have been developed at the IAT (www.iat.eu) and provide a methodology designed to study the time-space dynamics of knowledge and ways of knowledge integration with innovation processes. They allow capturing relationships, contextual settings and different kinds of knowledge, by providing insight into the evolution and development of social innovations (Pelka and Terstriep, 2016).

Within the projects about eco-innovation like EFEB we will adapt the methodology of IBs from other projects like SIMPACT and SI-Drive (www.iat.eu) for EIBs.

By following the process of creation with narrative interviewing methods and triangulation, the biography of an innovation is constructed including the evolution of related knowledge. Data collection belongs to sectoral as well as local, regional or national categories, and sheds light on cross-sectoral knowledge combinations and its multiscale reach. 
Three dimensions of an eco-innovation process will guide the selection of instruments: the time dimension for caching the evolvement of knowledge dynamics, their multilevel and combinatorial character, social interactions and network of actors involved into innovation.

These three dimensions are the fundament of methods applied: Insights into the time space dimension are obtained through tools of biographical research (Butzin and PICBE | 1056 Widmaier, 2016). This is done by following the life story of an eco-innovation through a narrative story and interviews with an actor of the innovation process.

Egocentric network analysis was chosen to make visible the actors, their location and content of interaction. Time space path is a mean to combine the data as only their ensemble as a whole constitutes the EIB. Preparation and narrative interview are two ways of starting the research process.

\section{Conclusions}

It is important for research work to be used by SMEs, entrepreneurs and policy makers i.e. for building eco-innovation models and that they have benefits from research results. But first, it is important that researchers understand SME needs and cooperate with them.

In the cooperative work with SMEs is also necessary to identify research and innovation gaps and ask SMEs if they are interested in the eco-innovation topic.

It is necessary to consider education, entrepreneurial culture, personal formation, on each stage of development of eco-innovation models.

Meanwhile development models should work in innovative eco-systems, and functional complex that creates competitiveness and added value.

Tax incentives, economic instruments and financial instruments to stimulate private investment and building a business oriented model, are neccesary.

A dynamic and stimulative VC market, supporting by business angels, is an essential condition for the success of eco-innovation.

We want to remember a quote by Victor Hwang (author of Innovation Rainforest) who said that "Economies thrive when culture (...and formation is part of the entrepreneurial culture) overcomes social barriers and fosters connectivity, trust, and collaboration between diverse people...". Think about that.

\section{References}

Amit, R. and Zott, C. (2001). Value creation in e-business, Strategic Management and the Environment, Innovation Policy and the Economy 4, 35-68.

Assante, D., Castro, M., Hamburg, I., and Martin, S. (2016). The use of cloude computing in SMEs. In: Procedia computer science 83, special issue: The 7th International Conference on Ambient Systems, Networks and Technologies (ANT 2016) / The 6th International Conference on Sustainable Energy Information Technology (SEIT2016) / Affiliated Workshops, 1207-121.

Butzin, A. and Widmaier, B. (2016). Exploring territorial knowledge dynamics through innovation biographies. In: Regional studies, 20(2), 220-232.

Environmental Technologies Action Plan (ETAP): http://ec.europa.eu/environment/ecoap/ about-action-plan/etap-previous-action-plan_en. 
Competitiveness and Innovation Framework Program (CIP): http://www.europarl.europa.eu/RegData/etudes/etudes/join/2013/490672/IPOLJOIN_ET(2013)490672_EN.pdf.

Edward L. Vine, Drury Crawley and Centolella, P. (eds.), Energy Efficiency and for an Energy Efficient Economy in Harvard Business School Press.

Jaffe, A: G, Newell, NG and Stavins, R. (2004). Technology Policy for Energy and the PICBE| 1057 Environment, in Innovation Policy and the Economy, 4, 35-68.

Hamburg, I. (2014). Improving young entrepreneurship education and knowledge management in SMEs by mentors. In: World journal of education, 4(5), 51-57.

Hamburg, I. (2015). Learning approaches for entrepreneurship education. In: Advances in social sciences research journal, 3(1), 228-237.

Kaenzig, J., and Wüstenhagen, R. (2008). Understanding the Green Energy Consumer. Marketing Review St.Gallen (4), 12-16.

Kempton, W. (1991). Lay perspectives on global climate change. Global Environmental Change, 1(3), 183-208.

Linder, J.C. and Cantrell, S. (2000). Changing Business Models: Surveying the Marketing Review St.Gallen 4(4), 12-16.

Osterwalder, A. and Pigneur, Y. (2009). Business model generation, Communications of AIS, Volume 15, Article 17 Clarifying Business Models: Origins, Present, and Future of the Concepts.

Pelka, B. and Terstriep, J. (2016). Mapping social innovation maps: the state of research practice across Europe. In: European public \& social innovation review, 1(1), 3-16.

Rappa, M. (2001). Managing the digital enterprise, North Caroline State University. The Environment: Forging the Link, 29-69. Washington, D.C.: American Council.

Schmid, P., Alt, R., Zimmermann, R. and Buchet, B. (2001). Anniversary Edition: Anniversary Edition: Business Models, electronic Markets 11(1), 3-9.

Timmer, M. (1998), Business Models for Electronic Markets, EM Đ Electronic Markets

Turban, E. (2002), Introduction to E-Commerce, Prentice Hall.

Weill, P. and Vitale, R. (2001). Place to space: Migrating to e-business models, Harvard Business.

Vladut, G. (2017). Innovation Ecosystem model for commercialization of research results,

Fulga, S., Vladut, G., Marin, A., Hadar, A., Badea, D. M., Ciocanel, B., Bucur, D., Ivan and I., Boanta, L., Business models for increasing technological transfer effectiveness, Forum for Innovation, 13-14 October 2016, Bucharest, http://arott.ro/forum2016/conferinta.

Vladut G., Chiran D. and Lashyna Y., Knowledge Transfer Community to bridge the gap between research, innovation and business creation, Forum for Innovation, 13-14 October 2016, Bucharest, http://arott.ro/forum2016/conferinta. 